\title{
DAILY JOURNAL WRITING TO ENHANCE STUDENTS' WRITING SKILLS
}

\author{
Ester Eveline Sihite and Debora Chaterin Simanjuntak \\ English Education Department. Universitas Advent Indonesia \\ e-mail: esterevelinsihite@gmail.com
}

\begin{abstract}
This study aims to enhance students' writing skills through Daily Journal writing. This research was divided into three stesps: giving pre-test, giving treatment (writing daily journal), and giving posttest. The result showed significant difference between control and experimental group. Experimental participants was improved through the writing of daily journal, and the score gained by participants showed that there was a significant effect on students' writing skills. The achievements showed that the mean difference of post-test scores between the two groups was -.45433 and for the standard error mean was .03840 with pValue 050 (see Table 3), means that $H_{a}$ is accepted and $H_{o}$ is not accepted. It means, writing daily journal is strong enough to improve the students' writing skills.
\end{abstract}

Keywords: Journal Writing, Writing Skills, Daily Journal Variations

\section{INTRODUCTION}

As it is known, besides reading, speaking, and listening, writing is one of the most important skills, and need to be developed especially in learning English. (Douglas, 1994). A study showed that the ability to write is not an option but a necessity, or obligation for everyone (Alliance, 2006); writing helps learners to develop ideas or thoughts (Watson, 2001). Writing is an art in teaching and learning, which can teach you how to study in a right way. In other words it is a duty of an educator to guide students, so that they can learn and study better by training them in writing (Scott, 2008).

Writing is not as simple as it seems. To get ideas in writing, students should read a lot before they write. However, there are many students who have low motivation level in reading and if there is no passion for reading it will be difficult for students to develop mechanism of writing: to plan paragraph, to edit errors, to organize ideas, and so forth (Bacha, 2010). Gupta (2010) added that students should not feel unmotivated when they are not able to produce good writing. Writing in the classroom is an important academic requirement, but writing outside of the classroom can be a useful tool to improve writing skills. To become a good writer, students 
should practice continuously, namely, by buying a small notebook and try to write their daily activities. It will make student interested in page by page (Chanderasegaran, 2002). A study stated that one way to practice writing at home is through writing a journal in a form of a notebook, where the author or the writer will write the ideas, opinions, and descriptions of everyday life. Daily Journal writing helps students to create a better day from day to day, because that would give freedom to the students to write about what they want (Hamp \& Heasley, 2006). It helps students develop their creativity (Spaventa, 2000). The fact that students are given more opportunities to write about something which is relevant to them, called "active learning method" (Chickering \& Gamson, 1987). By writing journal, students can record their personal activities. The value of a personal writing has been discussed by several scholars such as Artof (1992) quoted in Tin (2000) It is a great tool to showcase one's untapped creative power, learn to see the world more clearly, heal unsolved issues, understand our fears, and explore his motivation. Therefore keeping a journal is an enjoyable activity because the primary purpose of writing a journal is to motivate students to be immersed in writing, without involving a lot of errors and time pressure (White \& Arndt, 1991). Writing journal gives students an excellent opportunity to improve their writing ability, skill and a good opportunity to record their thoughts and feelings (Ngoh, 2002). Furthermore Lagan (2002) provided multiple benefits in Daily Writing Journal, such as, writing a journal will help students develop the habit of thinking on paper and show you how the idea can be found in the process of writing, and a journal can make writing as a picture of their lives.

By writing a journal instead of to improve the ability of writing, it is also helps someone to pour thoughts on paper correctly, that shows the correlation between the accuracy of a clear thinking with the accuracy of quoting teachers words when teaching in the class. Dowrick (2009) said that it is briefly explained that if somone does not think clearly, he is not able to write clearly. Teachers are the best observers in all the passion and interests of each student. That knowledge is what will determine what kinds of journal that they like and enjoy to do or write. Stillman (1989) describes the types of journals as described below:

Everyday Activities' Journal: this form is a form of journal or diary that writes all daily activities such as attend summer camp, winter holiday, or other activities. It is not limited by the timing of when and how long the experience happen. And this activity experienced to be written every day, complete with punctuation.

Scrapbook Journal: many teens feel comfortable with the form of this journal. Because it is usually the merger or the combination of the various kinds of photographs, advertisements, and souvenirs. For example, if a student ever attended a prom, then she would write into a diary or a journal by sticking from a variety of souvenirs such as attaching prom invitations, 
flowers, or pictures with friends, overall describe or explain how the prom go on.

Brief Journal (Time in a capsule): This journal is part of the scrapbook journals, but the type of journal is more complete and concise answers. Example questions such as: How can you arrive at school? How much money do you handle? Are you saving up for something special? How tall and weight? What do you do when you have spare time? What types of activities do you often do? What subject do you like at school? And others. And can also include images from magazines, newspapers or the pictures in it.

Cassanave (1993) says that by writing a journal of the memories, they will be trained to be more creative and also train them to love writing. Porter et al (1996) concluded that through journal writing students will be able to develop a professional approach to language learning and writing. Dick (1983) showed that one technique to lead a class is introspection. And that introspection is through journal writing, where teachers can introspect and communicate to students through the writing of daily journal (Bailey, 1990; Porter et al. 1996).

Therefore this study is about how to enhance writing skills through Daily Journal writing (Hyland, 2004).

\section{METHODOLOGY}

The participants who have been chosen in this study are the second year of junior or middle high school students at SMP Negri 1 Parongpong. They are devided into two groups; control and experimental groups, each consists of 30 participants. The participants for the control group were grade VIII G, while for the experimental group were grade VIII B. The reasons why the group was chosen because most of the middle high school students, like things that can express themselves and their own feelings. Therefore, one way to support that desire is to write a daily journal. This study is based on four skills or expertise that are included in English, they are speaking, listening, reading, writing. And writing is one of the skills that the students should have and master in it.

The research instruments of this study are pre-test and post-test. The objectives of the pre-rest were to see the background and the extent of the capabilities or the expertise of the students' writing skills. In this study, there were two groups: experimental and control group. To see a comparison of the results of writing between the pre-test and post-test, the experimental group was given treatment to to write interesting Daily Journal. In the treatment, students were also taught how to use punctuation correctly, providing vocabularies that is very often used in everyday conversation, and also teach a term called onomatopoia the use of words (such as "hissing", "giggling" etc.) that imitate the sound that associated with the object or 
action they see or feel. While for the control group was given conventional treatment. After giving treatment, then follows a post-test, to see if there is any progress and ijmpact on their writing skills after being given treatment. And to assess the outcome of the final result, at the end of this study.

To do the scoring, the writers calculated students' writings based on a rubric; in which, using five categories and each category can be scaled from 1 up to 4 points (rubric is attached).

\section{Presentation and analysis of data}

In this part, the writers used six factors or formulas to calculate all of the data. First, calculating the average using the mean formula. Second, calculating the standard deviation to to know how much the dispersion exists from the average (mean) value. Third, calculating the standardized of the gain to find out the improvement after giving the treatment to the two groups. Fourth, calculating the normality of the data to know whether the data are normally distributed or not. Fifth, calculating the homogeneity of the data to know the data between two groups for the post-test scores wether they are similar or homogen in nature or not. Sixth, calculating the independent $t$-test, to determine that the data between two groups are not overlapping and not depend on other.

a. Calculating the mean of the pre-test scores for the control group

$$
\begin{aligned}
& \overline{\mathrm{X}}=\frac{\sum \mathrm{x}}{\mathrm{n}} \\
& \overline{\mathrm{X}}=30.74 \\
& \overline{\mathrm{X}}=\text { Mean of the pre-test } \\
& \sum=\text { Sum of the scores } \\
& \mathrm{X}=\text { Individual observation } \\
& \mathrm{n}=\text { The total number of observations/ pariticipants }
\end{aligned}
$$

b. Calculating the mean of the pre-test scores for the experimental group

$$
\begin{aligned}
& \bar{x}=\frac{\sum x}{n} \\
& \bar{X}=44.63
\end{aligned}
$$

\section{c. Calculating the mean of the post-test scores for the control group}




$$
\begin{aligned}
& \bar{x}=\frac{\sum x}{n} \\
& \bar{X}=40.18
\end{aligned}
$$

d. Calculating the mean of the post-test scores for the experimental group

$$
\begin{aligned}
& \overline{\mathrm{x}}=\frac{\sum \mathrm{x}}{\mathrm{n}} \\
& \overline{\mathrm{X}}=78.24
\end{aligned}
$$

e. Calculating the standard deviation of the pre-test for the control group

$$
\begin{aligned}
& =\sqrt{\frac{\sum(x-\bar{x})^{2}}{n-1}} S_{D} \\
S_{D} & =7.12
\end{aligned}
$$

f. Calculating the standard deviation of the pre-test for the experimental

$S_{D}=\sqrt{\frac{\sum(x-\bar{x})^{2}}{n-1}}$

$S_{D} \quad=12.90$

g. Calculating the standard deviation

$S_{D}=\sqrt{\frac{\sum(x-\bar{x})^{2}}{n-1}}$ the post-test for the control group

$S_{D} \quad=12.03$

h. Calculating the standard deviation of the post-test for the experimental $S_{D}=\sqrt{\frac{\sum(x-\bar{x})^{2}}{n-1}}$

$S_{D} \quad=8.11$ 


\section{i.Standardized Gain}

$$
\text { Gain }=\frac{(\text { post-test })-(\text { pre-test })}{(\text { ideal })-(\text { pre-test })}
$$

Ideal $=36($ perfect score $)$

\section{Table 1}

Test of Normality

\begin{tabular}{|c|c|c|c|c|c|c|c|}
\hline & \multirow[b]{2}{*}{ Kode } & \multicolumn{3}{|c|}{ Kolmogorov-Smirnov ${ }^{\mathrm{a}}$} & \multicolumn{3}{|c|}{ Shapiro-Wilk } \\
\hline & & Statistics & $\mathrm{Df}$ & Sig. & Statistic & Df & Sig. \\
\hline \multirow[t]{2}{*}{ Data } & Control & .186 & 30 & .010 & .867 & 30 & .001 \\
\hline & Experimental & .146 & 30 & .101 & .940 & 30 & .093 \\
\hline
\end{tabular}

a. Lilliefors Significance Correction

\section{According to the results it is concluded as follows:}

The data of the control group was not normally distributed because Sig.(.010) $<\alpha$ (.050), it means $\mathrm{H}_{\mathrm{o}}$ is not accepted. The data of the experimental group was normally distributed because Sig.(.101) $>\alpha(.050)$, it means $\mathrm{H}_{\mathrm{o}}$ is accepted.

\section{Table 2}

Test of Homogeneity of Variance

\begin{tabular}{|l|r|r|r|r|}
\hline & Levene Statistic & df1 & df2 & \multicolumn{1}{c|}{ Sig. } \\
\hline Data $\quad$ Based on Mean & 4.779 & 1 & 58 & .033 \\
& 3.631 & 1 & 58 & .062 \\
Based on Median & 3.631 & 1 & 52.201 & .062 \\
Based on Median and with & & & & \\
adjusted df & & & & \\
Based on trimmed mean & 4.766 & & 1 & .033 \\
\hline
\end{tabular}


Based on the statistics, if one of the data was not normally distributed, then for the homogeneity test, used the data based on median. (see Table 1). And, according to the result, it is shown that the data between the two groups for the posttest scores are homogen because Sig. (.062) $\geq \alpha(.050)$, it means that $\mathrm{H}_{\mathrm{o}}$ is accepted.

Table 3

Independent Samples Test

\begin{tabular}{|c|c|c|c|c|c|c|c|c|c|c|}
\hline & \multicolumn{2}{|c|}{$\begin{array}{c}\text { Levene's Test } \\
\text { for Equality of } \\
\text { Variances }\end{array}$} & \multicolumn{7}{|c|}{ t-test for Equality of Means } \\
\hline & & \multirow[b]{2}{*}{$\mathrm{F}$} & \multirow[b]{2}{*}{ Sig. } & \multirow[b]{2}{*}{$\mathrm{T}$} & \multirow[b]{2}{*}{ Df } & \multirow[b]{2}{*}{$\begin{array}{l}\text { Sig. (2- } \\
\text { tailed) }\end{array}$} & \multirow[b]{2}{*}{$\begin{array}{c}\text { Mean } \\
\text { Difference }\end{array}$} & \multirow[b]{2}{*}{$\begin{array}{l}\text { Std. Error } \\
\text { Difference }\end{array}$} & \multicolumn{2}{|c|}{$\begin{array}{c}95 \% \text { Confidence } \\
\text { Interval of the } \\
\text { Difference }\end{array}$} \\
\hline & & & & & & & & & Lower & Upper \\
\hline Data & $\begin{array}{l}\text { Equal variances } \\
\text { assumed }\end{array}$ & 4.779 & .033 & -11.832 & 58 & .000 & -.45433 & .03840 & -.53120 & -.37747 \\
\hline & $\begin{array}{l}\text { Equal variances } \\
\text { not assumed }\end{array}$ & & & -11.832 & 50.947 & .000 & -.45433 & .03840 & -.53142 & -.37724 \\
\hline
\end{tabular}

Therefore, as explained at the Table 3 it is shown that Sig. $(.000) \leq \alpha(.050)$. It means, $\mathrm{H}_{\mathrm{a}}$ is accepted and $\mathrm{H}_{\mathrm{o}}$ is not accepted. Therefore, the conclusion is, giving treatment through the writing of daily journal, is giving effect in improving writing skills.

\section{CONCLUSION}

After a careful analysis, the writers drew the conclusion as follows: Writing Daily Journal Strategy succeeded on improving writing skills. It was shown by the Ttest scores between both groups as explained in chapter four at table 3. Writing Daily Journal Strategy makes the students feel free to write, they can express their own feelings, teach them more creative and they know where their strengths and 
weaknessness in writing, and they can learn from their own mistakes. Writing daily journal can motivate the students to generate their ideas easily. The students showed that they were motivated to write new vocabularies that the researcher taught them to write.

\section{RECOMMENDATION}

From the conclusion above, some recommendations are recommended as an effort to increase the uses of writing daily journal strategy in teaching english writing. Writing daily journal can be used as an alternative form in teaching writing to the middle high school students. In teaching writing through daily journal, the teacher should let them to create their own creativity, so that they can explore their minds, feeling, dreams, and imagination freely. The teacher should know that writing activity using daily journal could be implemented to enhance students' vocabulary. For other researchers who want to use Writing Daily Journal in order to improve students' writing skills, should consider these factors: There are so many kinds or types of daily journal that can be used in teaching writing skills and this strategy can be used or conducted to middle high school levels.

\section{REFERENCES}

Alliance. Writing Next: Effective strategies to improve writing of adolescents in middle and high school. A report to Carnegie Corporation of New York. Washington, DC: Alliance for Excellent Education; 2007.

Alwasillah, (1997). "Intelectuals Lack writing skills". Universitas Pendidikan Indonesia (UPI)

Artof, S.D. (1992). Use of Personal Writing for Personal Growth. In Tin, T.B. (2004). Creative Writing in EFL/ESL Classrooms. University Putra Malaysia Press publisher

Bacha, N.N. (2010). Developing learners' academic writing skills in higher education: a study for education reform. Journal of Language and Education.

Bailey, K.M, (1990). The Use of Diary Studies in Teacher Education Programs. Cambridge : Cambridge University Press publisher

Casanave, C.P. (1993). Reading and Responding: Using Journals. In New Ways in Teaching Reading, (pp. 149-156). Alexandria, Virginia: Teachers of English to Speakers of Other Languages, Inc.

Chanderasegaran, A. (2002). Intervening to Help in the Writing Process. RELC Portfolio Series 7.

Chickering, A.W. \& Gamson, Z.F. (1987). Seven Principles for Good Practice in Undergraduate Education. AAHH Bulletin. 
Dick (1983). Classroom-Centered Research on Language Teaching and Learning: A brief Historical Overview. TESOL Quarterly, 17(2), 191-202.

Douglas, Brown. H (1994). Principles of language learning and teaching. 3rd edition. Englewood Cliffs, NJ: Prentice Hall Regents.

Dowrick, S. (2009). Creative journal writing: the art and heart reflection. Penguin Group Inc.

Gupta, R. (2010). How to write and speak correct English. Lotus Press.

Hamp-Lyons, L. \& Heasly, B. (2006). Study Writing (2nd Ed.). Cambridge:

Cambridge University Press.

Hyland, (2004). Disciplinary interactions: Metadiscourse in L2 postgraduate writing. Journal of Second Language writing, 13, 133-151.

Lagan, J. (2000). College Writing Skills. London: Longman University

Ngoh, T.J. (2002). From Journals to Weekly Papers. Guidelines, Vol. 24, June 2002.

Porter, P.A., Goldstein, L.M., Leatherman, J. \& Concad, S. (1996). An Ongoing dialogue: Learning Languages for teacher preparation. SLT.

Scott, J. (2008). Daily writing journal. Prestwick House Inc.

Spaventa, S. (2000). Essay Writing. Cambridge: Cambridge University Press.

Stillman, Peter R (Writer's Digest Books, 1989). Sixty imaginative, playful and meaningful writing activities that can build links across generations, now and in the future.

Tin, T.B. (2000). Creative Writing in EFL/ESL Classrooms. Universiti Putra Malaysia Press.

Watson, (2001). "Giving feedback on journals" ELT Journal, 2001 - Oxford Univ Press

White, R. \& Arndt, V. (1991). Process Writing. London: Longman. 